the leaves and dead areas on the petals, together with more or less deformation of the blossoms. Spots at first orbicular and definite in outline but later becoming confluent and irregular. Acervuli numerous, $5^{\circ}-150 \mu$ in diameter, often confluent ; stroma usually only slightly
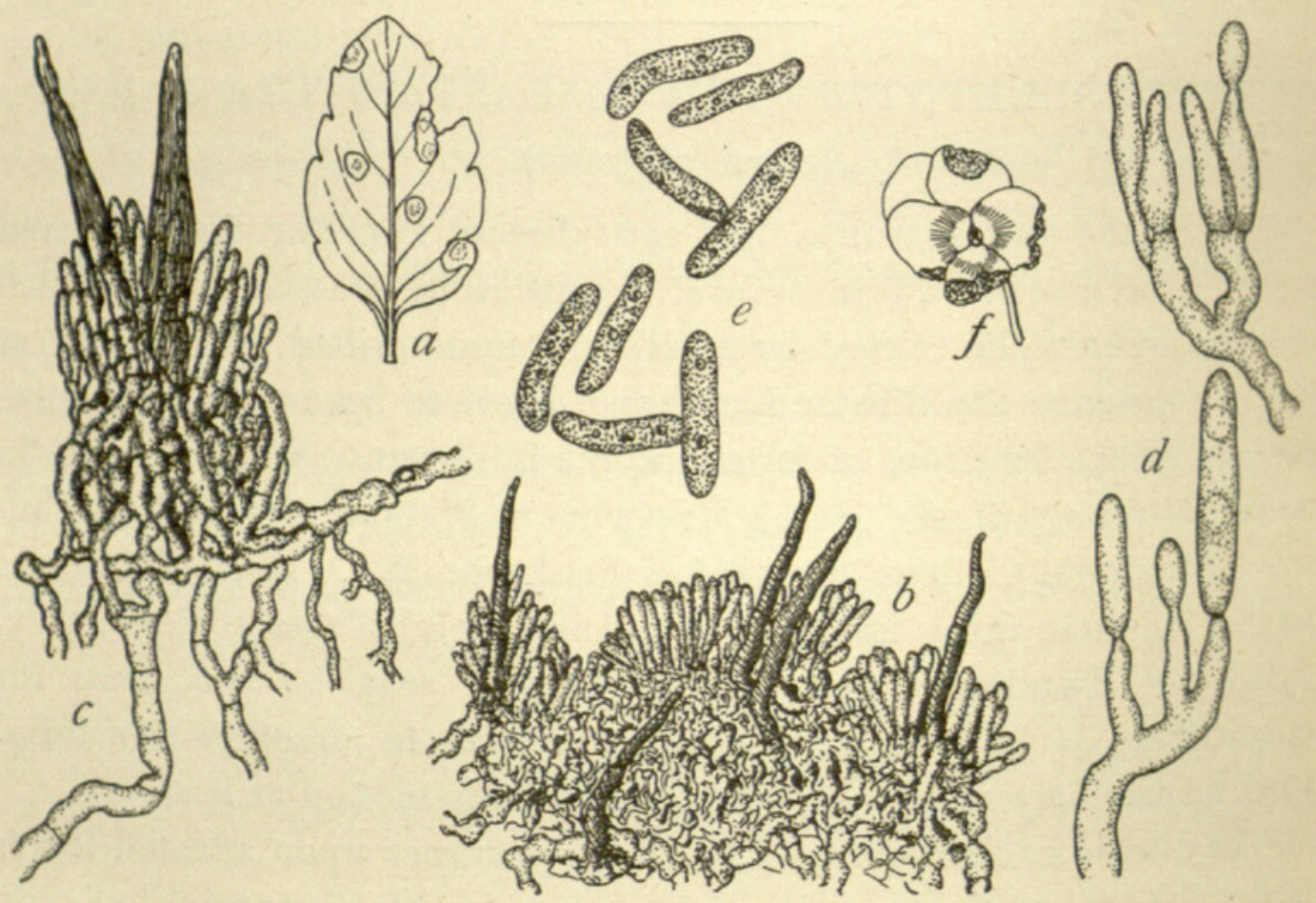

Fig. i. Colletotrichum viole-Tricoloris R. E. Smith: $a$, affected leaflet; $b$, several confluent acervuli with mycelium, setæ, and conidia; $c$, single acervulus, more enlarged; $d$, basidia and production of conidia; $e$, conidia; $f$, affected blossom.

developed but sometimes abundant and forming a sort of pycnidium, closely approaching Vermicularia. Setæ mostly single or in pairs, 20-70 $\mu$ long, deep brown, once or twice septate, tapering gradually to a point. Basidia short, hyaline. Conidia oblong or slightly curved, with blunt ends; hyaline, continuous, granular with vacuoles; averag. ing $20 \times .5 \mu$.- Ralph E. Smith, Amherst, Mass.

\title{
A NEW BIENNIAL-FRUITED OAK.
}

\section{(WITH PLATES II, III)}

Quercus ellipsoidalis, n. sp.- Trees $3^{-10^{\mathrm{dm}}}$ in diameter, $8-20^{\mathrm{m}}$ tall, with an oblong head, the spray fine and repeatedly dividing, the limbs often descending low down on the trunk and the lowermost drooping. The bark is close, rather smooth, divided by shallow fissures into nar- 
row, thin, flat plates, $5^{-\mathrm{I}} 5^{\mathrm{cm}}$ long, $\mathrm{I} \cdot 5^{-}-3 \cdot 5^{\mathrm{cm}}$ thick, frequently connected by cross plates. It is darkish colored near the ground, dull gray above and grayish-brown among the branches, where it is quite smooth and but little furrowed. It is coarsely cellular, dull red within, with a thin band of yellow or yellowish bark $I-2^{\mathrm{mm}}$ thick next the wood. The smaller branches are lustrous, the older being green tinged with red. Those of the second year are greenish-brown to olivaceous, those of the year brown to reddish-brown, both often mottled with spots or areas of gray. The younger are well furnished with small, grayish, oblong or roundish, raised lenticels. The winter buds are $4-8^{\mathrm{mm}}$ long, ovate, obtuse or acutish, sometimes slightly angled. The scales are ovate to oval, ciliolate, the outer brown to reddish-brown, with a rusty or grayish pubescence, the apex blunt or rounded. The unfolding leaves are spreading or a little drooping, often slightly tinged with red, densely covered with white tomentum, giving the foliage a silverygray appearance. The stipules are $\mathrm{I} 2-\mathrm{I} 5^{\mathrm{mm}}$ long, scarious or membranaceous, caducous, oblanceolate-linear to linear, hairy on the margin and with a few scattered hairs on the surface. The leaves soon become smooth and lustrous green above, lighter green and smooth beneath or with slight tufts of pale hairs in the axils of the principal veins. They are from $6-\mathrm{I} 5^{\mathrm{cm}} \operatorname{long}, 5^{-1} 2^{\mathrm{em}}$. wide, oval-orbicular or somewhat obovate-orbicular in outline, the broadest part usually just above the middle, and are deeply cut into $5^{-7}$ lobes by broad sinuses The lobes are generally oblong, the terminal broader and somewhat quadrangular, their sides nearly parallel or a little diverging above the middle. They end in three to five triangular teeth with slender bristles. The base of the leaf is bluntly cuneate to truncate, the parenchyma on long side usually a little lower. The petioles are rather slender, $2.5-5^{\mathrm{em}}$ The color of about $4^{\mathrm{cm}}$ ), usually tinged with red on the upper. side. brown, more the autumn leaves varies, but in most is yellowish to pale change to a vinous blotched or tinged with red or purple. Some appearance. In the crimson purple, giving the tree a dark reddish The aments the winter they are pale brown. puberulent, from are in clusters, slender, $5^{-8^{\mathrm{cm}}}$ long, loosely flowered, into leafy shoots. lateral buds which after flowering may be prolonged tinged with vinous. The calyx is membranaceous, campanulate, usually oblong, oval, ovate 
the number and depth of the divisions. A frequent form of calyx is one divided to the base on the side next to the rachis, the margin two or three-lobed or parted. The segments are smooth or slightly scab. rous with a few minute scattered hairs, the tips copiously fringed with long, flattish, twisted or curling hairs. Stamens four or five, about the length of the calyx lobes. Anthers longer than the filaments, oblong, with a cordate base and blunt or emarginate apex which is sometimes apiculate.

The pistillate flowers are from the axils of leaves on fresh shoots of the year, their peduncles stout and very tomentose, and one to three-flowered. The calyx is tubular campanulate, the upper part generally strongly tinged with vinous red, and is four to seven-lobed, cleft or parted, the margin laciniate hairy and fringed with usually long hairs. Styles three, spreading or recurved, thick and flattish, hairy near the base, the enlarged rounded or knoblike stigmas dark colored and slightly two-lobed. The involucral scales are hairy, commonly reddish, mostly broad and blunt-pointed. There is often a basal lanceolate and bract-like scale. The acorns are single or in pairs, the cup turbinate or cup-shaped, thinnish, covering one third to one half or more of the nut and commonly tapering into a peduncle $8-15^{\mathrm{mm}}$ long. In some forms the cup is thickened near the margin, forming a kind of shoulder (plate $I I, f)$. The scales are narrow-ovate, obtuse or truncate, brownish, pubescent, closely appressed, sometimes a little loosened near the rim on drying. The margin is thin, hyaline, and slightly eroded. The cup within is puberulent, pale brown, the thin margin with a more deeply colored, reddish or yellowish ring. The nut is chestnut-brown, often striped with darker lines, puberulent, $\mathrm{I} 2-20^{\mathrm{mm}}$ long, $\mathrm{IO}-\mathrm{I} 5^{\mathrm{mm}}$ wide, ellipsoidal, varying from a cylindrical to a shorter somewhat globular form. The kernel is pale yellow and bitter, at least to the after taste.

Quercus ellipsoidalis more closely resembles Q. palustris in general appearance than the other common biennial oaks of the vicinity. There are also strong reminders of $Q$. coccinea and $Q$. velutina. It shares with $Q$. palustris a comparative smoothness of bark for an oak, the depressed lower limbs often coming low down on the trunk, the finely divided leaves and the general character of its branching, but the lobs. tion of the leaves, the inner bark, and especially the acorns, are different. It has the smoothest bark of any except this and young boles of Q. rubra, which it also resembles in the smoothness and color of the 
trunk after branching, as well as the larger branches themselves, in these characters. The smaller lower branches readily die off like those of $Q$. palustris but do not leave the prominent stubs so characteristic of the pin oak. The tinge of dark color low down on the trunk, the thin layer of yellow bark next to the wood, the coarse-grained wood itself, the presence of hairs in the axils of the veins of the leaf, the relatively dull color of the autumn leaves, suggest $Q$. velutina, but it does not have the roughness and blackness of bark which the black oak shows very early in its growth; there is much less yellow in the bark itself, and it has an acorn different in form and very unlike in the scales of the cup.

When first observed in the fall of $189 \mathrm{I}$, with some misgivings it was called $Q$. coccinea, partly on account of the acorns, which in general appearance are more like some forms of fruit in this species, and partly on account of a tendency to red, of a purple or crimson cast, however, seen in some of the autumn leaves. Its leaves also divide more like those of $Q$. coccinea and it has the reddish tinge of the inner bark, but the leaves do not turn scarlet in autumn, the outer bark is darker colored and much less rough and broken than on boles of $Q$. cocinea of similar age or size. It is also far less lichen-covered than trunks of $Q$. coccinea (generally it is comparatively free from lichens),
for the scarlet oak seems preeminently chosen among the black oaks by these plants, which sometimes are so close and large as nearly to conceal the color of the bark and at once reveal its specific character.

Hybridity was thought of and was suggested by others; a cross be added. But coccinea and velutina, though palustris might almost as well tion, even if they the trees are too numerous to resort to this explanaprobable for species. it spreads over an area of Glenwood in this of several acres, and is equally common south ward to Q. rubra; in county. In the first locality it gives place eastvelutina and coccinea. the southern limits of Where first found, at Gardner's Park near rubra is near by. Lake Michigan, grows in clay soil. extending northward with from these three localities, that of Glenwood have not detected 
nately were cut down before they could be fully studied suggest its presence north of the city in the vicinity of Winnetka.

That it differs from the ordinary black oaks to the eye of other than botanical observers is evident from the fact that an intelligent farmer had separated it from its congeners, calling it "yellow oak," and remarking the tendency of the lower limbs to die. No chestnut oaks, to which this name commonly applies, grew there, so that it could in no way be confounded with this, even if the leaves were not so different. Looked at in the summer it gives the impression of great leafiness, the leaves being small as a whole, and of airiness on account of its glossy and finely divided leaves. In the winter it impresses by the glitter of its smooth bright branches when free from leaves, and by its great twigginess, due to the spray repeatedly and finely dividing, forming an irregular network as one looks through it.

As the form of the acorns first suggested specific difference, and on the whole is the most constant characteristic, the name Quercus ellip. soidalis seems most appropriate.-E. J. Hill, Chicago, Ill.

\section{EXPLANATION OF PLATES II AND III.}

Plate II.-Quercus ellipsoidalis Hill.-- $a$, Flowering branch, natural size ; $b$, staminate flower, enlarged nine diameters ; $c$, pistillate flower, enlarged nine diameters; $a$ leaf, natural size; $e, f$, acorns, natural size.

Plate III.-Quercus ellipsoidalis Hill.-- $a$, Fruiting branch, five sixths natural size; $b$, nut, natural size; $c$, vertical section of nut, natural size; $d$, seed, natural size; $c$ winter branchlet.

\section{THE WYOMING SPECIES OF ANTENNARIA.}

Most valuable and efficient work has been done recently by Drs. Greene $^{x}$ and Rydberg ${ }^{2}$ in the long neglected genus Antennaria. A critical examination of the material in the Herbarium of the University of Wyoming in the light of these contributions has led to the discovery of a few forms, hitherto undescribed, which seem worthy of specific rank. It has seemed well, also, to make mention of all Wyoming species of which specimens are at hand.

Antennaria reflexa, n. sp.- Low and cespitose, somewhat sublig. neous at base, with very short leafy offsets : stems $5^{-10^{\mathrm{cm}}}$ high: leaves

${ }^{x}$ Pittonia 3 : 172, 273, 289 .

${ }^{2}$ Bull. Torr. Bot. Club $24: 299$. 


\section{$2 \mathrm{BHL}$ Biodiversity Heritage Library}

Hill, E J . 1899. "A New Biennial-Fruited Oak." Botanical gazette 27(3), 204-208. https://doi.org/10.1086/327814.

View This Item Online: $\underline{\text { https://www.biodiversitylibrary.org/item/94861 }}$

DOI: https://doi.org/10.1086/327814

Permalink: https://www.biodiversitylibrary.org/partpdf/222952

\section{Holding Institution}

Missouri Botanical Garden, Peter H. Raven Library

\section{Sponsored by}

Missouri Botanical Garden

\section{Copyright \& Reuse}

Copyright Status: Public domain. The BHL considers that this work is no longer under copyright protection.

This document was created from content at the Biodiversity Heritage Library, the world's largest open access digital library for biodiversity literature and archives. Visit BHL at https://www.biodiversitylibrary.org. 